\title{
On the Development Direction and Policy of Chinese School Physical Education under the Background of 'Healthy China 2030 Program'
}

\author{
Jing $\mathrm{Li}^{1}$ and Seung-Yong $\mathrm{Kim}^{2}$ \\ ${ }^{1}$ Doctoral student, Dept. of Physical Education, Graduate School, Dong-A University, Korea \\ ${ }^{2}$ Assistant Professor, Major in Physical Education, Graduate School of Education, Dong-A University, Korea
}

\begin{abstract}
Background/Objectives: Based on the program of "Healthy China 2030" issued by Chinese government, this article takes approaches of both literature analysis and logical analyze the development direction and summarize the current existence of Chinese school Physical Education. Methods/Statistical analysis: This paper adopts the method of combining literature and logical analysis to collate, analyze and integrate domestic and foreign policy documents, papers and newspapers on "healthy China 2030, school physical education, lifelong sports, and physical health of teenagers". Findings: School physical education is an important basis for the implementation of the "Healthy China 2030 program". In order to achieve the goal of the healthy China, monitoring policy and physical education evaluation system should be improved; the problem of urban and rural physical education teachers should be solved to ensure the status of physical education teachers in teaching; more support and looser policies should be offered from government for school sports education; an integrated mutual assistance physical education model "government-school-family-society" should be promoted. Improvements/Applications: Combining with the development mode of school physical education in some developed countries and following the requirements of healthy China, this article offers suggestions for Chinese school physical education reform in the new period.
\end{abstract}

\section{Index Terms}

Healthy China 2030 Program, School Physical Education, Adolescents, Physical Health

\author{
Corresponding author : Seung-Yong Kim \\ dragonkim@dau.ac.kr \\ - Manuscript received February 19, 2019. \\ - Revised March 7, 2019; Accepted March 20, 2019. \\ - Date of publication March 31, 2019. \\ (c) The Academic Society of Convergence Science Inc. \\ 2546-1583 $\odot 2017$ IJEMR. Personal use is permitted, but republication/redistribution requires IJEMR permission.
}




\section{INTRODUCTION}

In recent years, with the great attention from the government, Chinese school physical education(PE) has achieved some results. However, seen from the whole, school physical education is still a weak part in the whole education work. There are still many problems exist in school physical education, such as inadequate PE courses, the shortage of professional PE teachers, insufficient PE funding, lack of sports facilities, low PE teaching quality, and incomplete evaluation system[1].

In addition, the latest "National Constitution Monitoring Bulletin" reports a continuous downward trend in students' physical fitness, a younger trend of students' visual acuity, and an uprising trend of students of all ages[2]. At present, the physical quality of Chinese students is lower than the world average quality. Thus, the question of how to improve the physical fitness of students has become a focus and hotspot in China[3].

Mao Zedong has mentioned in the "Sports Research": "Physical education should be connected with both moral and intellectual education. Since the physical condition is the base of morality and wisdom, without physical education, there would be no moral and intellectual education." $\mathrm{He}$ fully emphasizes the importance of sports, regarding sports as the foundation of both moral and intellectual education[4].

Though the government has issued a number of school sports guidance documents, it works slightly in changing the current status of school physical education. The 'healthy China 2030 program' is prompted under the new national health situation, appealing for new requirements and standards for the development of Chinese school sports. In August 2016, The 'Health China 2030' program, which has a clearer goal and a more accurate path, has been adopted and issued by the political bureau of CPC central committee with the consent of President $\mathrm{Xi}$ Jinping. Therefore, how to properly carry out the work of school physical education at present and how to better apply to the school sports in accordance with the policies of the healthy China implemented by the state to the school education are two realistic and inevitable problems that the school sports reform needs to solve.

\section{RESEARCH METHOD}

This paper adopts the method of combining literature and logical analysis to collate, analyze and integrate domestic and foreign policy documents, papers and newspapers on "healthy China 2030, school physical education, lifelong sports, and physical health of teenagers", In addition, this paper aims at under standing the main content and goals of Health China 2030, discussing the development direction of school sports, finding the problem of school sports and proposing corresponding solutions.

Table 1. MAIN HEALTH INDICATORS OF "HEALTHY CHINA 2030" PROGRAM

\begin{tabular}{|c|c|c|c|}
\hline field & Project & 2020 & 2030 \\
\hline \multirow{5}{*}{$\begin{array}{l}\text { Health } \\
\text { level }\end{array}$} & Life expectancy & 77.3 & 79.0 \\
\hline & Infant mortality & 7.5 & 5.0 \\
\hline & $\begin{array}{l}\text { Child mortality under } 5 \text { years } \\
\text { old }\end{array}$ & 9.5 & 6.0 \\
\hline & Maternal mortality & 12.0 & 18.0 \\
\hline & $\begin{array}{l}\text { Proportion of the number of } \\
\text { people who have passed the } \\
\text { physical examination } \\
\text { standard (\%) }\end{array}$ & 90.6 & 92.2 \\
\hline \multirow{2}{*}{$\begin{array}{l}\text { healthy } \\
\text { lifestyle }\end{array}$} & $\begin{array}{l}\text { Residents' health literacy } \\
\text { level (\%) }\end{array}$ & 20 & 30 \\
\hline & $\begin{array}{l}\text { Number of people taking } \\
\text { regular physical exercise ( } 100 \\
\text { million) }\end{array}$ & 4.35 & 5.3 \\
\hline \multirow{3}{*}{$\begin{array}{l}\text { Health } \\
\text { service }\end{array}$} & $\begin{array}{l}\text { Premature death from major } \\
\text { chronic diseases }(\%)\end{array}$ & $\begin{array}{l}10 \% \\
\text { lower } \\
\text { than } \\
2015\end{array}$ & $\begin{array}{l}20 \% \\
\text { lower } \\
\text { than } \\
2015\end{array}$ \\
\hline & $\begin{array}{l}\text { Number of practicing } \\
\text { (assistant) physicians per } \\
1,000 \text { permanent residents } \\
\text { (person) }\end{array}$ & 2.5 & 3.0 \\
\hline & $\begin{array}{l}\text { Personal health expenditure } \\
\text { as a percentage of total health } \\
\text { expenditure }(\%)\end{array}$ & 28 & 25 \\
\hline \multirow[t]{2}{*}{$\begin{array}{l}\text { Healthy } \\
\text { environme } \\
\text { nt }\end{array}$} & $\begin{array}{l}\text { Number of days with good air } \\
\text { quality in district and above } \\
\text { cities }(\%)\end{array}$ & $>80$ & $\begin{array}{l}\text { Continu } \\
\text { ous } \\
\text { improve } \\
\text { ment }\end{array}$ \\
\hline & $\begin{array}{l}\text { Surface water quality is better } \\
\text { or better than Class III water } \\
\text { body ratio }(\%)\end{array}$ & $>70$ & $\begin{array}{l}\text { Continu } \\
\text { ous } \\
\text { improve } \\
\text { ment }\end{array}$ \\
\hline $\begin{array}{l}\text { Health } \\
\text { industry }\end{array}$ & $\begin{array}{l}\text { The total size of the health } \\
\text { service industry (trillion } \\
\text { yuan) }\end{array}$ & $>8$ & 16 \\
\hline
\end{tabular}

Note: The data comes from the 'Healthy China 2030'

\section{Theoretical BACKGROUND}

\section{A. Background and key health indicators of healthy China 2030}

'Health China 2030' planning refers to the institutional documents that have been made to better protect people's health by 2030, Its core is to take the national health as the center, promotes the national health development. Health should include material, mental, behavioral and other dimensions, involving physical, psychological, social and lifestyle aspects[5]. 
The main health indicators in the 'Health China 2030' program are shown in <Table 1>. By 2020, the basic medical and health system should cover urban and rural residents. The health level should keep rising. The health service system should be improved, and a health industry system should be basically formed. By 2030, the system of promoting national health will be more perfect, the health field will be more coordinated, and a healthy lifestyle will be popularized. Physical health will reach national standards and quality of health services will be continuously improved. By 2050, A healthy country with a socialist modernized country will be built[6].

\section{B. References}

'Healthy China' clearly emphasizes a healthy lifestyle that all citizens can participate and enjoy. It Promotes participation in sports activities of a target group, implement youth sports activities, and develops youth sports hobbies to achieve the life of young people's fitness[7]. According to the statistics of the National Statistical Yearbook 2016, the current number of students in China is 266 million. At the end of 2018, the total population of mainland China was 1.395 billion[8].

This data shows that school sports may have a direct impact on one-fifth of the population of the strategic subjects of "healthy China" program. The school has specialized physical education teachers and sports venues and facilities. Through physical education, students are able to master relevant sports knowledge, skills, methods, and scientific exercising methods. Students' exposure to sports at school may help develop their interest and hobbies in sports, making students actively exercise at school or outside the school and thus keep health.

As mentioned in <Table 2>, In order to guarantee that young students participate in sports activities more than three times a week, with moderate intensity, and to make the "national student health standards" excellent compliance rate of more than $25 \%$, school physical education and training should be taken as indispensable part. It is an key part in training young people to master exercising skills and cultivate healthy lifestyles[9].

Table 2. Healthy Chinese Fitness Activity Goals

\begin{tabular}{l|l}
\hline $\begin{array}{l}\text { Fitness } \\
\text { activities }\end{array}$ & Aims \\
\hline Adult & $\begin{array}{l}\text { Actively participate in national fitness; } \\
\text { Promote the fitness of the whole nation }\end{array}$ \\
\hline & $\begin{array}{l}\text { Proficiency in more than 1 sports skill; } \\
\text { school sports activities are not less than 1 hour } \\
\text { a day; } \\
\text { teenagers } \\
\text { Participate in moderate intensity physical } \\
\text { activities more than 3 times a week; } \\
\text { National students' physique health standards } \\
\text { reached the excellent rate of more than } 25 \%\end{array}$ \\
\hline
\end{tabular}

\begin{tabular}{|c|c|}
\hline $\begin{array}{l}\text { safety } \\
\text { measures }\end{array}$ & $\begin{array}{l}\text { Construction of a county-level rural three- } \\
\text { level network of county and village public } \\
\text { sports facilities; } \\
\text { Public sports facilities are free or open for low } \\
\text { fees; } \\
\text { Strengthening the network construction of the } \\
\text { national fitness organizations; } \\
\text { Carry out sports that the masses enjoy; } \\
\text { Strengthening sports medical integration and } \\
\text { non-medical intervention; } \\
\text { Enrich and improve the national fitness } \\
\text { system }\end{array}$ \\
\hline
\end{tabular}

A clear direction on the school sports work will not only change the present unvalued situation of sports, but also help emphasize the importance of school sports. It also matters in training a large number of sports talents for the society and promoting the development of 'healthy China'[10].

School physical education are related to the health of young students across the country, the health of the whole people, and also to the goal of achieving "healthy China."

\section{The development direction of school sports}

\subsection{The development direction of Chinese school sports under the background of 'healthy China'}

In recent years, due to the overall poor physical condition of the youth, the national government attaches great importance to school sports, and the worry and concern about the school sports from the whole society keep rising. As shown in <Table 3>, with the promulgation of healthy China 2030 policy, the state has included health education into the national education system and makes it an important part of quality education in all education stages. offering school sports a clear development direction as well[11].

The "Healthy China 2030 program" proposes that by 2030 , the school sports facilities and equipment allocation rate should reach $100 \%$. The construction of school sports facilities should be improved and content of school physical education curriculum should be enriched; national physique testing should be conducted, physical fitness monitoring system should be completed, national physique monitoring big data should be developed; the sports risk assessment system should be strengthened; more school sports programs should be designed; physical education curriculum should be arranged to promote the development of school physical education according to the physical fitness of students.

\subsection{The development direction of school sports in some developed countries}

Due to different political, economic, social, 
cultural, and especially educational development backgrounds, school sports guiding ideology and education goals vary. The educational thoughts of the US, Britain, Russia and other countries are reflected in the following aspects: (1) Health promotion has become the main goal of school sports in many countries[12,13], There are few other ideas in the school sports that can be widely applied like the concept of "health"; (2) The overall development of students' as an individual is highly emphasized. Student's individuality and self-fulfillment are fully respected; (3) The cultivation of students' lifelong sports awareness, attitudes and abilities are their general focuses. In terms of ability development, the mastery of motor skills is the focus; (4) The deep education in school sports and the realization of social values are their general pursuits; (5) Evaluation of the learning process is highly emphasized. These common guiding ideologies lay a common foundation and benefits for countries to determine their school sports development methods[2].

\subsubsection{Establishment of school physical education (PE curriculum) standards}

Driven by the emphasis on school physical education, all countries have formulated school physical education (PE curriculum) standards. In the process of formulation, government views are more or less reflected. The standards for School physical education (sports courses) in most countries are directly set and published by government educational institutions. However, it should also be noticed that the government management of school sports only exists in areas like rule setting and financial support. Government involves less and less in the detailed affairs of school sports. While social organizations begin to show a closer relation in school sports, especially extracurricular sports[2]. It has become a common trend among developed countries to use social resources to develop school sports, especially extracurricular sports.

\subsubsection{Ensure physical fitness and ensure participation in sports activities}

In order to better protect the participation of students in sports activities, developed countries pay more and more attention to the linkage between schools, communities and families in the process of school sports reform, making an increasing degree of social participation in school sports management. In order to ensure the physical health of students, developed countries like the United States, Britain, France, Australia, Japan, South Korea, Singapore, Russia have adopted policies to strengthen school sports, and made clear provisions on the aspects like time, content, site and teachers of physical education[14].

\section{Problems in Chinese SCHOol PHYSICAL EDUCATION}

\section{A. Inadequate policy monitoring and evaluation system}

Many studies at home and abroad have shown that monitoring and evaluating policy activities is an important tool for policy management $[15,16]$. Without a well-regulated system or tool of policy evaluation, it is impossible to effectively carry out targeted management. In recent years, the preassessment of education policies monitoring has attracted the attention from government departments and academic circles. However, problems like the top-down administrative imperative testing and evaluation, which may affect the authenticity and accuracy of monitoring information[17].

\section{B. Unbalanced Emphasis among Government, School, FamilyInadequate policy monitoring and evaluation system}

For a long time, some common problems have existed in China's education reform. For example, "more requirements in Government documents, while less specific implementation; More surface forms, less actual results; More self-praise, less external recognition; More temporary effects, less sustainable effects"[18]. Though government policy constantly mentions and repeatedly stresses the issue of the guarantee of students' physical exercise time, the implementation is always unsatisfying.

In the context of exam-oriented education, society evaluates the school quality through its graduation rate. Therefore, In order to pursue the rate of graduation, the subjects linked with exam-oriented education are set as the main subjects, and the rest are called secondary courses. Physical education is also divided into optional secondary classes. Even the one or two PE classed per week will be replaced by other main courses, The casually free-range teaching is common. The boring and less-efficient class is just to complete the school teaching task, In addition, the boring classwork is just to complete the school task, unable to mobilize the students' enthusiasm and consciousness.

\section{The lack of faculty and blurring dominant role of teachers}

At the current stage of the reform of school sports in China, physical education teachers generally lack the passion and endogenous motivation to actively 
reform the course and current situation[19]. For the sports reform, though the role of the government can't be ignored, the tole of PE teachers who are in the front line of education are irreplaceable. PE teachers enjoy the dominant position in the reform and development of school sports. At the national compulsory education stage, "the physical education teachers account for less than $5 \%$ of the total number of teachers are responsible for $11 \%$ of the total class hours of the teaching tasks[20].” In terms of the rural primary and secondary schools, the total number of shortage of PE teacher is up to 300,000 . what's more, the lack of professional quality of PE teachers is another problem in both urban and rural school.

\section{The Limitation of Monotonousness in School Physical Education Reform Model}

The reason why the school physical education reform is difficult to last is that it is limited to the reform within the school scope, lacks the necessary social environment support and strong social orientation action with unified direction. It also lacks the active cooperation of the family and the awareness of family sports training. Though the whole society neglect sports education, school physical education becomes the target of public criticism when the physical health of students declines[21]. The society requires school physical education reform, requires students to achieve health quality results, but does not carry out the corresponding supportive environment and conditions. The lack of social participation in social work makes the school sports reform model relatively exclusive and single formed[22].

\section{THE COUNTERMEASURES OF SCHOOL PHYSICAL EDUCATION IN THE CONTEXT OF 'HEALTHY ChINA'}

\section{A. Promote quality education, foster health priority, and lifelong sports}

"Healthy China 2030" incorporates health education into the national education system as an important part of quality education, It is an important embodiment of the concept of "health first", always putting the educational function of sports in the first place. The program appeals for reformation and innovation in the physical education and health curriculum teaching system to enhance students' health literacy[23]. Physical activity should be a way to Alleviate stress and share happiness, however, people's understanding of sports only stays in its function of physical exercise. Examination-oriented education is only one of the reasons. we should pay attention to the students quality, morally, physically, and artistically development simultaneously.

The environment in which families and schools, including public opinion, is critical to the healthy growth of adolescents. Family and society should pay attention to the concept of developing students' health first and lifelong sports.

\section{B. Strengthen the construction of the school teachers and improve the status of physical education teachers}

In order to solve the problem of lack of teachers, the school should actively require full-time physical education teachers and support sports teaching and research personnel according to the number of students and the amount of teaching work; A lot of attention and care should also be given to $\mathrm{PE}$ teachers and welfare benefits. Regularly encourage physical education teachers to conduct professional training and further study.

\section{Promote the "government-school-family- society" mutual assistance model to promote the healthy development of students' physical fitness}

School physical education can not simply be understood as the sports inside campus. Many developed countries have actively developed various models like the interactive sports between family and school[24]. According to the actual situation in China, the integrated sports model of "GovernmentSchool-Family-society" can be pioneered. This model relies to a large extent on organizations, in which institutions and measures are supporting conditions, Seen from a theoretical level. the establishment of an integrated educational organization can effectively maintain the operation of the integrated sports education network[25].

Therefore, firstly, a macro-protection at the national government level and a policy system which confirms to China's current condition and can effectively implement the youth's constitutional health and healthy China's are urgently needed. Secondly, school should improve their abilities and efficiency on the implementation of policies, the school as a major activity venue for young people, should be released from the traditional concept of physical education. After class, families need to actively pay attention to students' physical exercise, make full use of family sports and exercise, so that school sports and family sports work can be effectively combined, mutual assistance and common development. Finally, the public sports facilities should also be well managed, actively support school and family sports work, and create a good social environment for physical exercise. 


\section{CONCLUSION}

School physical education are an important basis for the implementation of the "healthy China 2030 program". Since teenagers are the hope of our society and country. To achieve the goal of healthy China, we should make students aware of the concept of "health first" and the importance of lifelong participation in sports, aiming at cultivating the well-rounded developed youth. In addition, policy monitoring and physical education evaluation system should be improved. Solve the strength of urban and rural physical education teachers as soon as possible to ensure the status of physical education teachers in teaching; The government should vigorously support school sports, implement policies more flexibly, and promote the "government-schoolfamily-society" integration and mutual assistance model in physical education. The value of school physical education in the healthy China 2030 program should be activated. School physical education reformation is not a short-term journey. It requires the attention of the whole society to achieve a truly healthy China and healthy sports

\section{REFERENCES}

[1] J. Q. Zhang, J. Wang \& T. Wang. (2015). School Physical Education in Developed Countries and its Enlightenment. Journal of Wuhan Institute of Physical Education, 49(10), 5-20.

[2] General Administration of Sport of China. (2016). National Physique Monitoring Bulletin. http;//www.gov.cn.

[3] X. Sun. (2016). Analysis of the Difficulties and Countermeasures of Current Junior Middle School Physical Education. Contemporary Sports Technology, 32(6), 112-113.

[4] Z. D. Mao. (1917). The Study of Physical Education. New Youth, 3(2).

[5] G. Y. Liu. (2016). Implementing Strategic of National Fitness, Promoting Construction of Healthy China. China Sport Science, 36(12), 3-10.

[6] The central committee of the communist party of china. (2016). "Healthy china 2030" program. People's Daily.

[7] The central committee of the communist party of china. (2016). "Healthy china 2030” program. Beijing, 1-6.

[8] Central People's Government of China. (2018). http://www.gov.cn/shuju/index.htm.

[9] W. P. Zhang, Z. B. Wang \& B. L. Wu. (2018). Policy Expression of School Sport from the Perspective of Healthy China. Journal of Beijing Sport University, 41(2), 94-100.

[10] H. J. Geng, L. J. Mi \& Z. Zhao. (2007). The relationship between school physical education and national fitness. Scientific Information, 12, 189-190.

[11] M. Ren \& Z. B. Yin. (2018). Analysis on the prospect of the development of school physical education in china under the background of "Healthy china". Journal of Hubei University of Science Technology, 38(2), 91-94.

[12] I. Waddington \& A Smith. (2000). Sport, Health and Drugs: A Critical Sociological Perspective. London: Routledge.

[13] R. Telama, H. Nupponen \& M. Pieron. (2005). Physical activity among young people in the context of lifestyle. European Physical Education Review. 11(2), 169-183.

[14] L. L. Hu. (2012). School Physical education must pay attention to it. http://www.moe.gov.cn

[15] K. Michael. (2003). Randomized evaluations of educational programs in developing countries: Some lessons. Am EconRev, 93(2), 102-106.

[16] UNDP. (2009). Monitoring and Evaluation for Development Results. Now York: A. K. Office.

[17] L. Y. Pan \& J. Wang. (2019). A Review of Policies on the Reform and Development of Physical Education after 40 Years of Reform and Opening Up. China Sport Science, 39(5), 13-25.

[18] K. N.Wu. (2013). Integrated Reform in the field of Education. Tsinghua Journal of Education, 34(1), 6-9.

[19] J. P. He, W. Q. Yang \& W. N. Han. (2014). Cultivating the "Micro Reform" Power of School Physical Education in China Under the Leading of Top-Level Design. Journal of Beijing Sport University, 37(12), 79-84.

[20] J. Wu. (2014). Physical education must assume the responsibility of the times. China School Physical Education, (1), 13 .

[21] D. F. Wang. (2013). Study the Spirit of the 18th national congress of the communist party of china. Journal of Physical Education, 20(1), 1-5.

[22] Y. Yang. (2014). Sports bundled by “Testing”: Reflection and criticism on the dilemma of school physical education development. Education Research and Experiment, (5), 62-66.

[23] S. Zheng, Z. P. Wang \& G. L. Jiang. (2017). The Necessity and Implementation Strategy of P.E. in schools under the Background of Constructing a Healthy China. China School Physical Education, 4(3), 6-14.

[24] A. F. Huang \& j. Wang. (2015). Current Ten Issues of School Physical Education in China. Journal of Beijing Sport University, 38(2), 95-99.

[25] Y. J. Song \& X. D. LI. (2003). Study of Network Mode for School, Family and Community Physical Education Integration in China. Journal of Beijing University of Physical Education, 26(3), 363-365. 
Table 3. Summary of Related Policies for Safeguarding of Physical Activities in National Schools

\begin{tabular}{|c|c|c|c|c|}
\hline $\begin{array}{l}\text { Issue } \\
\text { time }\end{array}$ & Policy name & Policy background & Policy element & Implementation path \\
\hline $\begin{array}{l}2015 . \\
5.15\end{array}$ & $\begin{array}{l}\text { 《Interim } \\
\text { Measures for } \\
\text { Risk Prevention } \\
\text { and Control of } \\
\text { School Sports》 } \\
\text { ( Teaching } \\
\text { Sports (2015) } \\
\text { No. 3 ) }\end{array}$ & $\begin{array}{l}\text { 《Implementation of the National } \\
\text { Medium- and Long-Term Education } \\
\text { Reform and Development Plan(2010- } \\
2020) 》 \text {, } \\
\text { 《Notice of the General Office of the } \\
\text { State Council on Forwarding Several } \\
\text { Opinions of the Ministry of Education } \\
\text { on Strengthening School Sports } \\
\text { Work》, } \\
\text { Solve the problems of participation in } \\
\text { winter, teaching quality, etc. due to } \\
\text { improper risk prevention and control in } \\
\text { school sports work }\end{array}$ & $\begin{array}{l}\text { Aiming at physical } \\
\text { education in school physical } \\
\text { education, extracurricular } \\
\text { sports activities, } \\
\text { extracurricular sports } \\
\text { activities, training, } \\
\text { competitions etc, } \\
\text { Constructing a risk } \\
\text { prevention and control } \\
\text { system for students to } \\
\text { participate in sports } \\
\text { activities }\end{array}$ & $\begin{array}{l}\text { 1. Require schools to establish } \\
\text { students' participation in sports } \\
\text { activity prevention and control } \\
\text { system, Take measures from } \\
\text { administrators, venue } \\
\text { equipment, health files, } \\
\text { activity content, activity } \\
\text { intensity, purchase insurance, } \\
\text { Buy insurance and other } \\
\text { measures to reduce the risk of } \\
\text { injury } \\
\text { 2. Establish an accident } \\
\text { handling system and clarify } \\
\text { responsibilities }\end{array}$ \\
\hline $\begin{array}{l}2017 . \\
2.14\end{array}$ & $\begin{array}{l}\text { 《Implementatio } \\
\text { n Opinions on } \\
\text { Promoting the } \\
\text { Opening of } \\
\text { School Sports } \\
\text { Venues to the } \\
\text { Society》 } \\
\text { ( Teaching Arts } \\
\text { (2017) No. } 1 \text { ) }\end{array}$ & $\begin{array}{l}\text { Implement the 《'Health China 2030'》 } \\
\text { Plan and the National Plan (2016-2020), } \\
\text { Solve the problem of idle stadiums and } \\
\text { low usage rates in School. Advocate the } \\
\text { principle of government leadership, } \\
\text { multi-party cooperation, and open to the } \\
\text { society based on schools }\end{array}$ & $\begin{array}{l}\text { Standardize the } \\
\text { management system of } \\
\text { sports venues, and } \\
\text { formulate standards for } \\
\text { opening hours, open } \\
\text { objects, charging standards, } \\
\text { and operating modes. }\end{array}$ & $\begin{array}{l}\text { 1. Enrich the sports activities } \\
\text { in the school, promote the } \\
\text { school physical education } \\
\text { curriculum, stadium } \\
\text { standardization } \\
\text { 2. School youth sports club, } \\
\text { The sports activity center can } \\
\text { cooperate with the school } \\
\text { gymnasium to expand the } \\
\text { youth sports organization. }\end{array}$ \\
\hline $\begin{array}{l}2017 . \\
10.10\end{array}$ & $\begin{array}{l}\text { 《School Sports } \\
\text { Aesthetic } \\
\text { Education Part- } \\
\text { time Teacher } \\
\text { Management } \\
\text { Measures》 } \\
\text { ( Teaching Arts } \\
\text { (2017) No. } 7 \text { ) }\end{array}$ & $\begin{array}{l}\text { Implementing the 《"Opinions of the } \\
\text { State Council on Strengthening the } \\
\text { Construction of Teaching Staff"》and } \\
\text { 《"Opinions of the General Office of the } \\
\text { State Council on Strengthening School } \\
\text { Physical Education to Promote the } \\
\text { Comprehensive Development of } \\
\text { Students' Physical and Mental Health"》, } \\
\text { Solve the shortage of physical education } \\
\text { teachers, integrate all resources to } \\
\text { improve the size of teachers and the } \\
\text { quality of teaching, and promote the } \\
\text { healthy development of students' } \\
\text { physical and mental health }\end{array}$ & $\begin{array}{l}\text { PE part-time teachers, as the } \\
\text { educational and training } \\
\text { personnel of school physical } \\
\text { education, extracurricular } \\
\text { sports activities, after- } \\
\text { school sports training and } \\
\text { competition, specific sports } \\
\text { skills and projects, } \\
\text { formulate relevant } \\
\text { recruitment conditions } \\
\text { management and protection }\end{array}$ & $\begin{array}{l}\text { 1. All regions shall be } \\
\text { encouraged to employ part- } \\
\text { time physical education } \\
\text { teachers to carry out relevant } \\
\text { activities as appropriate, and } \\
\text { teachers of other subjects shall } \\
\text { be prohibited from serving as } \\
\text { physical education teachers. } \\
2 \text {. To provide real-time } \\
\text { benefits such as remuneration } \\
\text { for part-time physical } \\
\text { education teachers who carry } \\
\text { out sports activities, to ensure } \\
\text { rights and legitimacy. }\end{array}$ \\
\hline
\end{tabular}

Note: The information comes from the documents of the Ministry of Education of China 